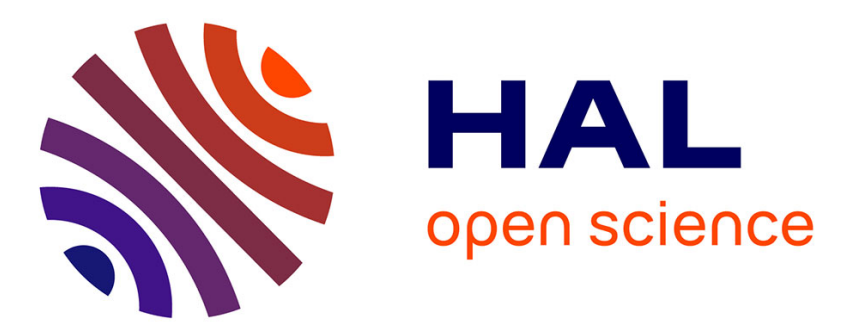

\title{
Evaluation of procalcitonin and CRP as sepsis markers in 74 consecutive patients admitted with prolonged febrile neutropenia
}

\author{
Jerome Cornillon, Marie Bouteloup, Claude Lambert
}

\section{To cite this version:}

Jerome Cornillon, Marie Bouteloup, Claude Lambert. Evaluation of procalcitonin and CRP as sepsis markers in 74 consecutive patients admitted with prolonged febrile neutropenia. Journal of Infection, 2011, 63 (1), pp.93-95. 10.1016/j.jinf.2011.05.010 . emse-00604229

HAL Id: emse-00604229

https://hal-emse.ccsd.cnrs.fr/emse-00604229

Submitted on 28 Jun 2011

HAL is a multi-disciplinary open access archive for the deposit and dissemination of scientific research documents, whether they are published or not. The documents may come from teaching and research institutions in France or abroad, or from public or private research centers.
L'archive ouverte pluridisciplinaire HAL, est destinée au dépôt et à la diffusion de documents scientifiques de niveau recherche, publiés ou non, émanant des établissements d'enseignement et de recherche français ou étrangers, des laboratoires publics ou privés. 


\title{
Evaluation of procalcitonin and CRP as sepsis markers in 74 consecutive patients admitted with prolonged febrile neutropenia
}

\author{
J ÉRÔME CORNILLON(1)* , MARIE BOUTELOUP(1), CLAUdE LAMBERT(2)
}

(1) Service d'Hématologie Clinique, Institut de Cancérologie de la Loire, 108, Bis Avenue Albert Raimond, 42055 St Etienne Cedex 2.

(2) Ecole Nationale Supérieure des Mines de Saint Etienne, Centre CIS - Axe des Systèmes Biologiques - LPMG UMR CNRS 5148, IFR 143 INSERM IFRESIS ; 158 Cours Fauriel 42023 Saint-Étienne Cedex 2, France

Keywords:

Fever ; bacterial infections; marker of inflammation ; PCT; procalcitonin ; CRP ;

Fever is a major event in critically ill patients. Its causes are difficult to identify and among them, bacterial infections must be rapidly identified and treated before sepsis reach a life threatening stage. CRP is a very sensitive marker of inflammation of whatever causes including sepsis. This is particularly crucial in immunocompromised patients. On the other hand, PCT has been extensively shown to be strongly and rapidly produced in bacterial infections only. Furthermore, PCT decreases very soon after bacterial resolution, and is thus a very useful in monitoring adequacy and efficiency of antibiotics. The utility of this marker in sever sepsis is now widely admitted. Recently, Limper et al. described biomarkers in discriminating infectious from non-infectious fever [1]. In new intensive chemotherapy strategies for the treatment of hemopathies as acute leukemia or bone marrow transplantation, profound and prolonged neutropenia ( $>7$ days) expose the patients to life threatening infections. In these high risk patients, infections are the main causes of fever and bacterial origins are particularly life threatening (septic shock, pneumonia, fungal infectious...). Immediate empirical broad-spectrum antimicrobial therapy improves the survival but is not always optimal and ineffective treatment must be changed as soon as possible $[2,3]$. A recent review identifies PCT as a valuable tool in early evaluation of antibiotherapy efficacy [4]. But this meta analysis also underlined that published data only come from small, retrospective and/or heterogeneous study groups and do not bring any proof of high standard of evidence. The only conclusive results have shown interest of PCT in short term neutropenia. But regarding more particular populations (i.e.: stem cell transplantation) no univocal conclusion is possible from the few published studies $[5,6]$.

In this study, we intended to evaluate the interest of PCT versus CRP in early evaluation of antibiotherapy efficacy. We have analyzed prospectively serum levels of PCT and CRP every morning from the entrance into the intensive care unit for predicted adverse outcome. The study was performed in the intensive care unit of hematology of the Oncology's Institute of StEtienne between September 2004 and July 2006. The monitoring concerned all consecutive patients who started an intensive chemotherapy program that induces prolonged neutropenia (>7 days). 74 patients were included. Among them, 44 were treated for leukemia's induction or consolidation with high dose of aracytin and 32 for bone marrow transplantation. PCT was measured by immunoluminometric LACE ${ }^{\circledR}$ technique on $\operatorname{Kryptor}^{\circledR}$ instrument according to manufacturer instructions (Brahms Diagnostica, Berlin, Germany) (normal value $<0.5 \mu \mathrm{g} / \mathrm{l}$; detection limit was $0.10 \mu \mathrm{g} / \mathrm{l})$, CRP was measured by nephelemetrie on BN ProSpec

* J erome.CORNILLON@icloire.fr 
instrument according to manufacturer instructions (Dade Behring, Siemens Germany) (reference value is $<10 \mathrm{mg} / \mathrm{L}$ ).

At admission, the mean granulocyte count was 3200/mm3 (40-16600). Only 9 patients presented granulocyte count below $500 / \mathrm{mm} 3$. All patients have developped a neutropénia and the median duration of neutropenia was 17 days (from 4 to 113). All patients had at least one fever episode, for a median duration of 2 days (1-14). Thirty-eight (51\%) episodes of fever were documented and considered to be related to bacteriema for $16(22 \%)$ patients or local infection such as urinary tract $(n=11 ; 15 \%)$, lung $(n=3 ; 4 \%)$, gut $(n=4 ; 5 \%)$, skin $(n=1 ; 1 \%)$ and ear or nose $(n=3 ; 4 \%)$. In these cases, bacteria were a Gram-positive $28 \%$ or Gramnegative $19 \%$ bacteria and other (4\%). coagulase negative Staphylococcus (14.8\%) (2 cultures were necessary for diagnosis), Streptococcus (12.1\%) and Escherichia Coli (9.5\%) were the most frequent bacteria involved.

At patient entrance, PCT and CRP levels were respectively $0.13 \mu \mathrm{g} / \mathrm{l}$ (range: $0.02-1.14$ ) and $22.7 \mathrm{mg} / \mathrm{L}$ (range: $3^{-271}$ ). The PCT or CRP levels at the first day of fever were not significantly raised compared to the levels at admission and were not significantly different between types of infections (Table 1). We did no find any significant cut-off using Roc curve analyses predicting the types of infections. Only 15 patients (21\%) reached a PCT level above $0.5 \mu \mathrm{g} / \mathrm{L}$ at first day of fever. In these patients, 12 patients presented documented bacterial infections. Majority of these patients presented a second febrile event (91\%). At level of 0.5, PCT was positive in $38 \%$ of bacteriema and in $27 \%$ of localized or undocumented bacteria. On the other hand, CRP at admission was significantly higher in patients who had serious events later (death or transfert in ICU) at entrance (63.7 vs. $16.3, p=.001$ ) Forty percents of the patients with CRP higher than $45 \mathrm{mg} / \mathrm{l}$ at admission presented serious event later (required intensive care with mechanical ventilation and/or eventually death) compared to $8 \%$ of the patients who had an initial CRP below this threshold.

Table 1. PCT and CRP levels of patients, correlated with the category in infection (days+1).

\begin{tabular}{|c|c|c|c|c|c|c|c|}
\hline & Undetermined & Pulmonary & $\begin{array}{l}\text { Blood } \\
\text { Isolation }\end{array}$ & $\begin{array}{l}\text { Urinary } \\
\text { Tract }\end{array}$ & Gut & Skin & ENT \\
\hline $\begin{array}{l}\text { Nb. of } \\
\text { patients }\end{array}$ & 36 & 3 & 16 & 11 & 4 & 1 & 3 \\
\hline \multicolumn{8}{|l|}{ PCT } \\
\hline $\begin{array}{l}\text { Median } \\
\text { (SD) }\end{array}$ & $\begin{array}{l}0.17 \\
(8.33)\end{array}$ & $0.66(3.56)$ & $\begin{array}{l}0.23 \\
(8.5) \\
\end{array}$ & $\begin{array}{l}0.15 \\
(3.34) \\
\end{array}$ & $\begin{array}{l}0.25 \\
(0.09) \\
\end{array}$ & $\begin{array}{l}0.15 \\
(0.06)\end{array}$ & $\begin{array}{l}0.19 \\
(0.06) \\
\end{array}$ \\
\hline \multicolumn{8}{|l|}{ CRP } \\
\hline $\begin{array}{l}\text { Median } \\
\text { (SD) }\end{array}$ & $\begin{array}{l}79.4 \\
(73) \\
\end{array}$ & $\begin{array}{l}75 \\
(67) \\
\end{array}$ & $\begin{array}{l}94 \\
(85) \\
\end{array}$ & $\begin{array}{l}69.6 \\
(61)\end{array}$ & $\begin{array}{l}54.9 \\
(8)\end{array}$ & $\begin{array}{l}73.2 \\
(-)\end{array}$ & $\begin{array}{l}30.2 \\
(-)\end{array}$ \\
\hline
\end{tabular}

ENT: Ear-Nose-Throat.

No difference was noted between categories, but pulmonary's infections are presented more elevated level of PCT.

It is the first time to our knowledge, that PCT predictive values have been analyzed in a prospective and exhaustive study. Because we have evaluated PCT values every day during neutropenia, we could analyze the dynamic of PCT during the very first $24 \mathrm{~h}$ of fever in this period. Interestingly, we could not find in these patients any significant raise and then any significant predictive value of PCT that could help in the guidance of the treatment as it was repeatedly reported in sepsis of patients with normal count of neutrophils. The poor rise of PCT levels could be related to the neutropenia and subsequently the lack of source and production [7]. Furthermore, because the diagnosis was made very early and the probabilistic treatment started immediately, it is possible that the PCT induction was killed in the egg, the infectious process being rapidly interrupted. This is in accordance with the short duration of fever events and previous reports [2]. And, fortunately, we had no real antibiotherapy failure that should have let the PCT raising. It is most probable that prophylaxis including gut decontamination (non absorbable by colymicin and gentamycin) and Fluconazole could have help in limiting the occurrence of serious events. 
In order to improve the specificity, manufacturer has proposed to use a cut-off at $2.0 \mathrm{ng} / \mathrm{mL}$ instead of $0.5 \mathrm{ng} / \mathrm{ml}$. This strategy was not relevant in our early treated patients, in accordance with Massaro [8] but this remains controversial [9, 10], probably due to the heterogeneity of the populations that have been studied. The basic PCT level was never significantly raised and the patient had no inflammatory syndrome as shown by low CRP levels. In our experience, PCT above $0.5 \mu \mathrm{g} / \mathrm{mL}$ was significantly associated with clearly documented bacterial infection (12/15 total patients) with a good positive predictive value (80\%). However, only $21 \%$ of patients were concerned and other fever events could either be related to a short-cut bacterial infection or other infectious causes that rapidly resolved with or without the help of the treatment.

Finally, incidentally, our study has shown a negative predictive value of CRP raise at the admission of the patient. This can be related to an underlying inflammatory process possibly related to the disease or some incidental pathology. This fact could justify more studies to identify possible incident pathologies that could cause a high co-morbidity that could be treated in order to reduce the risks for these patients. So, at admission, theses patients should be managed with great care and we should promptly anticipate any events in neutropenic period.

Thus, our study shows that early treatment of bacterial infection with probabilistic antibiotherapy could strongly reduce morbidity of febrile neutropenic patients according to the mean duration of the febrile episode and thus limit the PCT of PCT raise that was otherwise extensively demonstrated to be correlated to severe sepsis in non neutropenic patients.

\section{Disclosures}

None declared.

\section{Conflict of interest}

The authors had no conflicts of interest with any of the industrials cited in this report.

\section{Références}

[1] M. Limper, M.D. de Kruif, A.J. Duits, D.P. Brandjes and E.C. van Gorp, The diagnostic role of procalcitonin and other biomarkers in discriminating infectious from noninfectious fever, J Infect 6o (6) (2010), pp. 409-416.

[2] W.T. Hughes, D. Armstrong, G.P. Bodey, E.J. Bow, A.E. Brown and T. Calandra et al., Guidelines for the use of antimicrobial agents in neutropenic patients with cancer, Clin Infect Dis 34 (6) (2002), pp. 730-751.

[3] O. Penack, P. Rempf, M. Eisenblatter, A. Stroux, J. Wagner and E. Thiel et al., Bloodstream infections in neutropenic patients: early detection of pathogens and directed antimicrobial therapy due to surveillance blood cultures, Ann Oncol 18 (11) (2007), pp. 1870-1874.

[4] Y. Sakr, C. Sponholz, F. Tuche, F. Brunkhorst and K. Reinhart, The role of procalcitonin in febrile neutropenic patients: review of the literature, Infection 36 (5) (2008), pp. 396-407.

[5] N.M. Blijlevens, J.P. Donnelly, J.F. Meis, M.H. De Keizer and B.E. De Pauw, Procalcitonin does not discriminate infection from inflammation after allogeneic bone marrow transplantation, Clin Diagn Lab Immunol 7 (6) (2000), pp. 889-892.

[6] M. Ortega, M. Rovira, X. Filella, M. Almela, J. Puig de la Bellacasa and E. Carreras et al., Prospective evaluation of procalcitonin in adults with febrile neutropenia after haematopoietic stem cell transplantation, Br J Haematol 126 (3) (2004), pp. 372-376.

[7] M. Oberhoffer, I. Stonans, S. Russwurm, E. Stonane, H. Vogelsang and U. Junker et al., Procalcitonin expression in human peripheral blood mononuclear cells and its modulation by lipopolysaccharides and sepsis-related cytokines in vitro, J Lab Clin Med 134 (1) (1999), pp. 49-55. 
[8] K.S. Massaro, S.F. Costa, C. Leone and D.A. Chamone, Procalcitonin (PCT) and Creactive protein (CRP) as severe systemic infection markers in febrile neutropenic adults, BMC Infect Dis 7 (2007), p. 137.

[9] A. Engel, G. Steinbach, P. Kern and W.V. Kern, Diagnostic value of procalcitonin serum levels in neutropenic patients with fever: comparison with interleukin-8, Scand J Infect Dis 31 (2) (1999), pp. 185-189.

[10] M. Svaldi, J. Hirber, A.I. Lanthaler, O. Mayr, S. Faes and E. Peer et al., Procalcitoninreduced sensitivity and specificity in heavily leucopenic and immunosuppressed patients, Br J Haematol 115 (1) (2001), pp. 53-57. 